\title{
Cost concerns blamed for AIDS test hold-ups
}

Paris. François Gros, one of France's leading biologists and a former director of the Institut Pasteur, last week hit back at charges that in 1985 he and other officials delayed approval of an AIDS test marketed by Abbott Laboratories to protect the national market for a French test.

This so-called 'second' blood affair, which concerns an alleged delay in introducing routine screening of blood for antibodies to HIV, is distinct from an earlier case in which two officials were imprisoned for distributing unheated clotting factors contaminated with HIV to haemophiliacs, when they could have imported heat-inactivated products.

The new allegations were made in the newspaper Libération by Bernard Seytre the translator of Robert Gallo's book Virus Hunters - and are based on memoranda written by Gros and other government advisers in 1985 which have been leaked from a continuing judicial investigation.

Seytre claimed that other documents also show that officials delayed the Abbott test both because the test marketed by the French company Diagnostics Pasteur was not working properly before June 1985 and because the company was not yet in a position to meet demand. Diagnostics Pasteur denies both allegations.

Official documents reveal that the National Health Laboratory(NHL), France's equivalent of the US Food and Drug Ad- ministration, registered Abbott's application on 11 February 1985 and approved it on 24 July (the test had been approved in the United States on 2 March). The application from Diagnostics Pasteur was received on 28 February and approved on 21 June.

Memoranda also confirm that an interministerial meeting on 9 May 1985 chaired by Gros - who was then scientific adviser to Laurent Fabius, the prime minister - discussed at length whether to protect the Pasteur test.

An official from the health ministry told the meeting that a decision had to be taken quickly because the NHL "cannot hold back Abbott's application much longer beyond 13 May, the legal limit, without running the risk of a contentious appeal."

Gros admits that he tried to protect the Pasteur test, and says that there was concern that Abbott was making an aggressive attempt to invade the French market. "In the circumstances, it didn't appear to me to be shocking to keep a part of the French market for Pasteur," he says.

But Gros vigorously denies the main charge, namely that the government delayed introducing routine screening of blood because of this, arguing that the allegations cover only part of a more complex picture. He claims, for example, that the major consideration was not protectionism but cost, and that at the meeting on 9 May, the ministries of both finance and social affairs

\section{Delays 'fatally undermine' French claims}

Paris. The lawyer who acts for Robert Gallo claimed last week that allegations that the French government delayed the Abbott AIDS test to allow a French test to be released first (see above) "fatally undermine" France's attempts to renegotiate its 1987 settlement with the United States which provides for an equal split of royalties from the patent on the AIDS blood test.

This arrangement was initially reached following agreement that Gallo, of the US National Institutes of Health, and Luc Montagnier of the Institut Pasteur be acknowledged as 'co-discoverers' of the AIDS virus. Although a settlement cannot legally be renegotiated, French officials have argued that the United States is "morally" bound to give it a bigger share of the royalties, on the grounds that Gallo's published sequence is now acknowledged to be virtually identical to the French strain, which was itself contaminated.

"Why should the US think it owes the French anything when they barred the US blood test from the French markets for narrow commercial reasons, killing their own citizens?" asks Joseph Onek, of the Washington law firm Crowell and Moring.
Onek says he intends to bring the newspaper articles describing the actions of French officials to the attention of the US administration, and "point out the extraordinary audacity of the Pasteur".

But the delay to the Abbott test has not been proved to have held up the introduction of routine screening in France (see above). Moreover, while Seytre claims that the French test was unreliable until June 1985 , Françoise Brun-Vézinet of the Claude Bernard hospital in Paris - whose data are cited by Seytre - says that, although there was some variability between batches, the quality of the test itself was not a problem.

Nonetheless, the Diagnostics Pasteur test does not appear to have been ready when the company submitted it for approval on 28 February. "We were still testing it in April," says Brun-Vézinet.

Whether the new charges will affect negotiations between the French and United States on the AIDS patent is another matter. Despite French sabre-rattling, Montagnier has said that the chapter is closed, and France's conservative government is said to have little interest in pursuing the matter.

D. B. refused to meet the estimated FFr200 million (US\$32 million) annual cost of screening from health insurance funds.

Gros says this reluctance was partly due to an underestimation of the risk of posttransfusional AIDS; only four cases had

\section{IMAGE UNAVAILABLE FOR COPYRIGHT REASONS}

\section{François Gros: denies impropriety.}

been recorded in France in 1985 . He also says that Fabius and others were concerned about the consequences for people who tested positive.

This was a worldwide concern in 1985 . Peter L Page, of the American Red Cross Blood Service, wrote to Nature at the time suggesting that licensing should not occur until regional blood centres were able to implement the test with reasonable assurance that the number of false positives would be minimal, and the significance of antiHTLV-III test positivity was clearly understood (see Nature 313, 824; 1985). Page also warned that the available tests "could cause undue concern for some donors, while not removing from the blood supply all units potentially infective for AIDS"

Gros adds that some officials were concerned that the level of false positives could require too many blood donations to be discarded, and thus disrupt blood stocks.

Fabius announced the introduction of systematic screening of blood on 19 June 1985 , and most transfusion centres began on 1 August, making France one of the first countries to introduce screening. The UK government for example, introduced screening in the autumn of 1985 only after completing an evaluation of five AIDS tests in midsummer (see Nature 316, 474; 1985), the outcome of which favoured a British test marketed by Wellcome over the Abbott test.

What role - if any - protectionism by the French government played in the timing of the introduction of routine screening in France will probably be hammered out in court, as charges have been brought against Gros and other advisers relating to the affair. One of the questions to be answered is why the prime minister's office intervened in the procedures of the independent NHL.

Declan Butle 